\title{
TELIPOGON MAYOI (ORCHIDACEAE), A NEW SPECIES FROM WESTERN ANDES OF COLOMBIA
}

\author{
Guillermo A. Reina-Rodríguez ${ }^{1}$, Francisco López-Machado ${ }^{1} \&$ CARlos Martel $^{2,3}$ \\ ${ }^{1}$ Grupo de Investigación en Orquídeas, Ecología y Sistemática Vegetal, Universidad Nacional de \\ Colombia, Sede Palmira, Colombia \\ ${ }^{2}$ Instituto de Ciencias Ómicas y Biotecnología Aplicada, Pontificia Universidad Católica del Perú, Av. \\ Universitaria 1801, San Miguel 15088, Lima, Perú \\ ${ }^{3}$ Museo de Historia Natural, Universidad Nacional Mayor de San Marcos, Lima, Perú \\ *Author for correspondence: reirodriguez6@gmail.com
}

\begin{abstract}
Telipogon mayoi, from the western Colombian Andes, is proposed as a new species. The species was found in "La Elvira" National Protective Forest in the Yumbo Municipality, one of the oldest protected areas in Colombia, close to the Farallones de Cali National Park, both localities in the Dapa Mountains. Specimens of Telipogon mayoi were previously misidentified as Telipogon lankesteri Ames and T. williamsii P.Ortiz, but detailed analysis of the floral morphology revealed that it is different. Telipogon mayoi is most similar to T. lankesteri but it is characterized by the crenulated margins of the leaves (vs. entire margins), the ovate oblong lip (vs. oblong lanceolate) and furcate setae on the column (vs. simple setae). We provide a description, illustrations, a plate, in situ photographs, a distribution map, and ecological notes.

Resumen. Telipogon mayoi proveniente de los Andes occidentales de Colombia, es propuesta como nueva especie. La especie fue hallada en la Municipalidad de Yumbo en la Reserva Forestal Protectora Nacional "La Elvira", una de las áreas protegidas más antiguas de Colombia, cercana al Parque Nacional Natural Farallones de Cali, ambas localidades en las montañas de Dapa. Especímenes de Telipogon mayoi fueron previamente identificados como Telipogon lankesteri Ames y T. williamsii P.Ortiz, pero un análisis minucioso de la morfología floral reveló que tiene una identidad distinta. Telipogon mayoi es más similar a T. lankesteri pero se caracteriza por presentar márgenes crenulados en las hojas (vs. márgenes enteros), un labelo ovado oblongo ( $v s$. oblongo lanceolado), y setas furcadas en la columna ( $v s$. setas simples). Se provee una descripción, ilustraciones, una lámina, fotografías in situ, un mapa de distribución y notas ecológicas.

KEY Words: Andes, cloud forest, Colombia, miniature Telipogon, Oncidiinae
\end{abstract}

Introduction. Telipogon Kunth is a neotropical orchid genus, which currently contains around 260 accepted species (Martel unpublished data). Species of this genus can be found from southern Mexico to Central America, the Caribbean and in the Andes, from Venezuela to northern Bolivia between 500 and $3600 \mathrm{~m}$ (Martel \& Nauray 2013, Collantes \& Martel 2015). Telipogon species are usually associated as having colorful and showy flowers (see Dodson \& Escobar 1987, Dodson 2004). However, some Telipogon species possess very small and non-showy flowers; those species were formerly included in the genus Stellilabium. The genus Stellilabium was transferred to Telipogon based on molecular data (Williams et al. 2005). Recently, Martel et al. (2017) proposed to use the term "miniature Telipogon" to distinguish the Telipogon species that fit with the characteristics of the former Stellilabi$u m$. Thus, miniature Telipogon are characterized as be- ing small plants, usually less than $10 \mathrm{~cm}$, and flowers of less than $2 \mathrm{~cm}$ diameter (Martel et al. 2017). Despite the difference in size, morphologically, miniature $T e$ lipogon are consistent with flower morphology of the genus (e.g. usually non-resupinate flowers, lip similar to the petals, a robust and short column, and a pollinarium with four pollinia) and especially they present an uncinate viscidium (Martel et al. 2017). Although miniature Telipogon present broader distribution ranges compared to other Telipogon, they are not well represented in herbaria, because their small size makes them easily overlooked (Martel 2016a, 2016b, Martel et al. 2017). In Colombia, due to the complexity and variety of ecosystems, rainfall, microclimate diversity and orographic factors, there is still great orchids gaps as many areas are waiting for botanical exploration (Reina-Rodríguez 2016, 2019). Around 70 species of Telipogon occur in the country (Govaerts et al. 2019); 
however, Betancur et al. (2015) recognized only 67 species, of which 38 are endemic. Nevertheless, this number would be surely increased as new Telipogon species are recently being described from there (e.g. Kolanowska et al. 2017, Perez-Escobar et al. 2017).

In 2018 as part of a study for evaluate the climate change on orchids, in western Colombian Andes, diverse orchid plants were marked and codded in the wild. In 2019, during the monitoring of those plants, one member of the team noticed that a specimen codded as T. williamsii P.Ortiz, which occurs in the area, was different from the other plants also codded as T. williamsii. Furthermore, a similar specimen was published as $T$. lankesteri in a nearby location (i.e. Yumbo Municipality) some years ago (see Pérez-Escobar et al. 2011). A detailed examination of these plants revealed that they do not belong with those afore mentioned species, but to an undescribed species of Telipogon. Therefore, we propose this as a new taxon and provide here a description, illustrations and a distributional map of the species.

Materials and methods. Plant specimens were collected in "La Elvira" National Protective Forest Reserve in the Arroyohondo River Basin, Western Andes of Colombia. Plant material was preserved as voucher and in spirits in the herbarium (CUVC) at the Universidad del Valle in Cali. Photographs were taken in situ with a Cannon EOS 60D® using a $60 \mathrm{~mm}$ macro. Dissections of the plant and flower were arranged according to LCDP format and were edited with Adobe Photoshop ${ }^{\circledR}$ CS4. The spirit material was used to prepare the line drawing. Location map was prepared with ArcGIS 10, module ArcMap ESRI ${ }^{\circledR}$. The conservation assessment complies with the criteria of the IUCN (2019). To determine the weather conditions in Colombia, Ecuador and Costa Rica, the website (http://es.climate-data.org) was visited. Authors and names of plants follow the databases The International Plant Name Index (http://www.ipni. org), Tropicos (http://www.tropicos.org) and Epidendra (http://www.epidendra.org).

\section{TAXONOMIC TREATMENT}

Telipogon mayoi Reina-Rodr. \& C.Martel, sp. nov. (Fig. 1-3).

TYPE: Colombia. Valle del Cauca: Municipio de Yumbo, Corregimiento Dapa, Parcelación
Los Morales. Parcela Familia Rubiano-Hurtado. Microcuenca El Rincón, afluente del río Arroyohondo. Bosque subandino, $3^{\circ} 34^{\prime} 40.73^{\prime \prime} \mathrm{N} \quad 76^{\circ} 34^{\prime} 19.12^{\prime \prime} \mathrm{W}$, 2106 m, 16.VI.2019. fl., G. Reina-Rodríguez et al. 2982. (CUVC-in spirit!)

Diagnosis: Telipogon mayoi Reina-Rodr. \& C.Martel is similar to T. lankesteri, but differs by the crenulate margins in the leaves (vs. entire margins), the ovate oblong lip (vs. oblong lanceolate), ciliate margins of the lip (vs. entire margins), furcate setae on the column (vs. simple setae).

Plant epiphytic, $4.0-4.5 \mathrm{~cm}$ long, erect. Roots 9-16 mm long, adventitious, sinuous. Leaf 4, blade $4.0-8.0 \times 2.0-2.5 \mathrm{~mm}$, elliptical, smooth, apex acuminate, margin crenulate. Inflorescence $4.0-8.3 \mathrm{~cm}$ long, 1-2 branched, erect, flattened, racemose. Floral bracts $0.8-1.0 \mathrm{~mm}$ long, light green, decurrent, triangular-ovate, slightly winged, apiculate. Pedicels $0.8-1.0 \mathrm{~mm}$, erect, green. Flowers $6-8 \mathrm{~mm}$ in diameter, resupinate, one or two flowers open at a time, pedicelate; floral pedicels $0.8-1.0 \mathrm{~mm}$, erect, green. Ovary $1.3 \mathrm{~mm}$ long, light green, straight, with ribs. Sepals basal red wine color at the base, greenish yellow distally; dorsal sepal 4.0-4.2 × 1.8-2.0 mm, ovate, 1-veined, apex sub-acute, mucronate; Lateral petals $4.0-4.1 \times 1.8-2.0 \mathrm{~mm}$, ovate, 1-veined, apex acute to sub-acute, mucronate, basally red wine color, distal half greenish yellow. Lip 4.0-4.1 × 1.7-1.8 mm, ecallose, ovate oblong, 3-veined, ciliate margins, the hairs retorse, surface hirsute, apex sub-acute, mucronate. Column 1.5-1.7 × 1.0-1.2 mm, height, basally ovate, ventrally unguiculate, dorsally densely setose; stigmatic surface concave, lustrous; setae furcated, 3 tuffs. Anther cap $1.1 \times 1.3 \mathrm{~mm}$, cordate, red. Pollinarium $0.5 \times 0.3 \mathrm{~mm}$; pollinia 4 , yellow, obovate two pairs of different size; caudicle $0.5 \mathrm{~mm}$ diam., elastic, hyaline; viscidium orange, uncinate. Seed pod sub-spherical to ovoid.

Eponomy: The species is named after Mayo Rubiano, the youngest member of the team in Dapa, an orchid enthusiast and who first noticed that the plant designed as type here was different from $T$. williamsii.

Conservation status: An assessment of the conservation status of the new species cannot be made at this time due to only two locations (i.e. Yumbo Munici- 


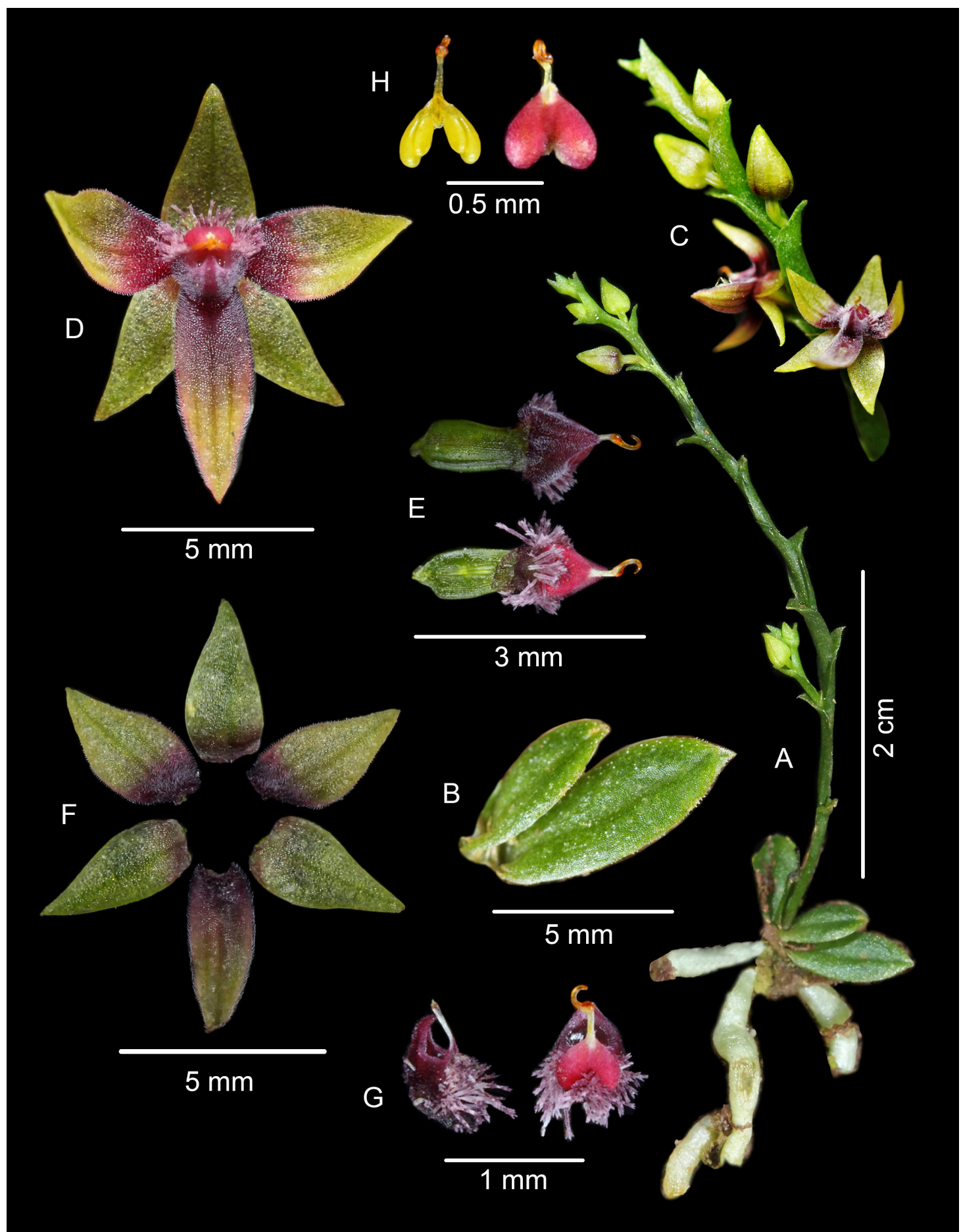

Figure 1. Telipogon mayoi Reina-Rodr. \& C.Martel. A. Habit. B. Leaves, upper view. C. Inflorescence, detail of the apex. D. Flower, frontal view. E. Ovary and column, ventral and dorsal views. F. Perianth, dissected. G. Column, lateral and dorsal views. H. Pollinarium without and with the anther cap. Photographs by G. Reina-Rodríguez and F. LópezMachado based on Reina-Rodriguez et al. 2982 (CUVC-in spirit). 


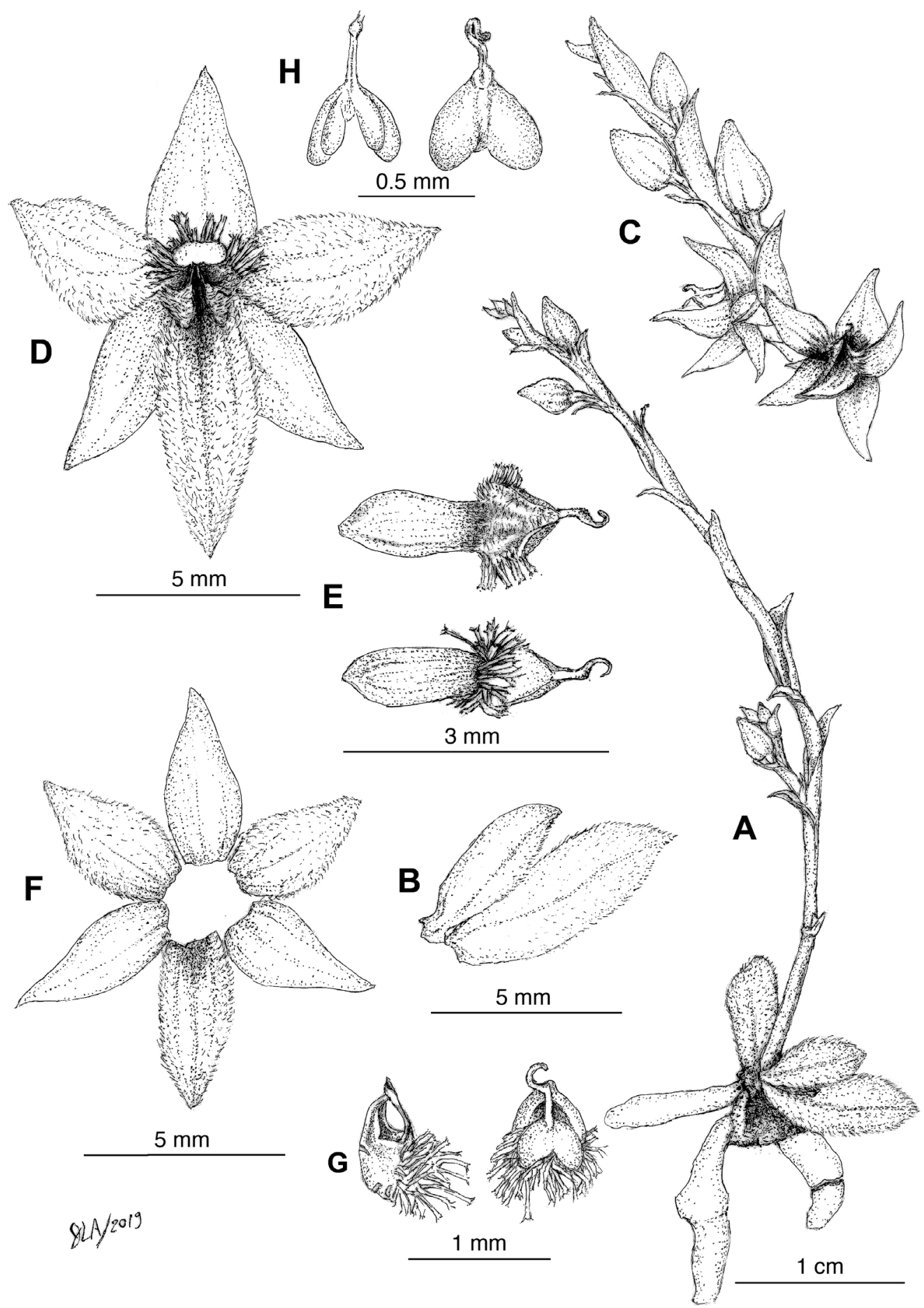

Figure 2. Line drawing of Telipogon mayoi Reina-Rodr. \& C.Martel. A. Habit. B. Leaves. C. Flowers in the inflorescence. D. Frontal view of the flower. E. Column, anther cap and bristles, ventral and dorsal views. F. Dissected perianth. G. Ovary and column, lateral and dorsal views. H. Pollinia without and with the anther cap. Drawn by Jairo Larrahondo based on Reina-Rodríguez et al. 2982 (CUVC-in spirit). 


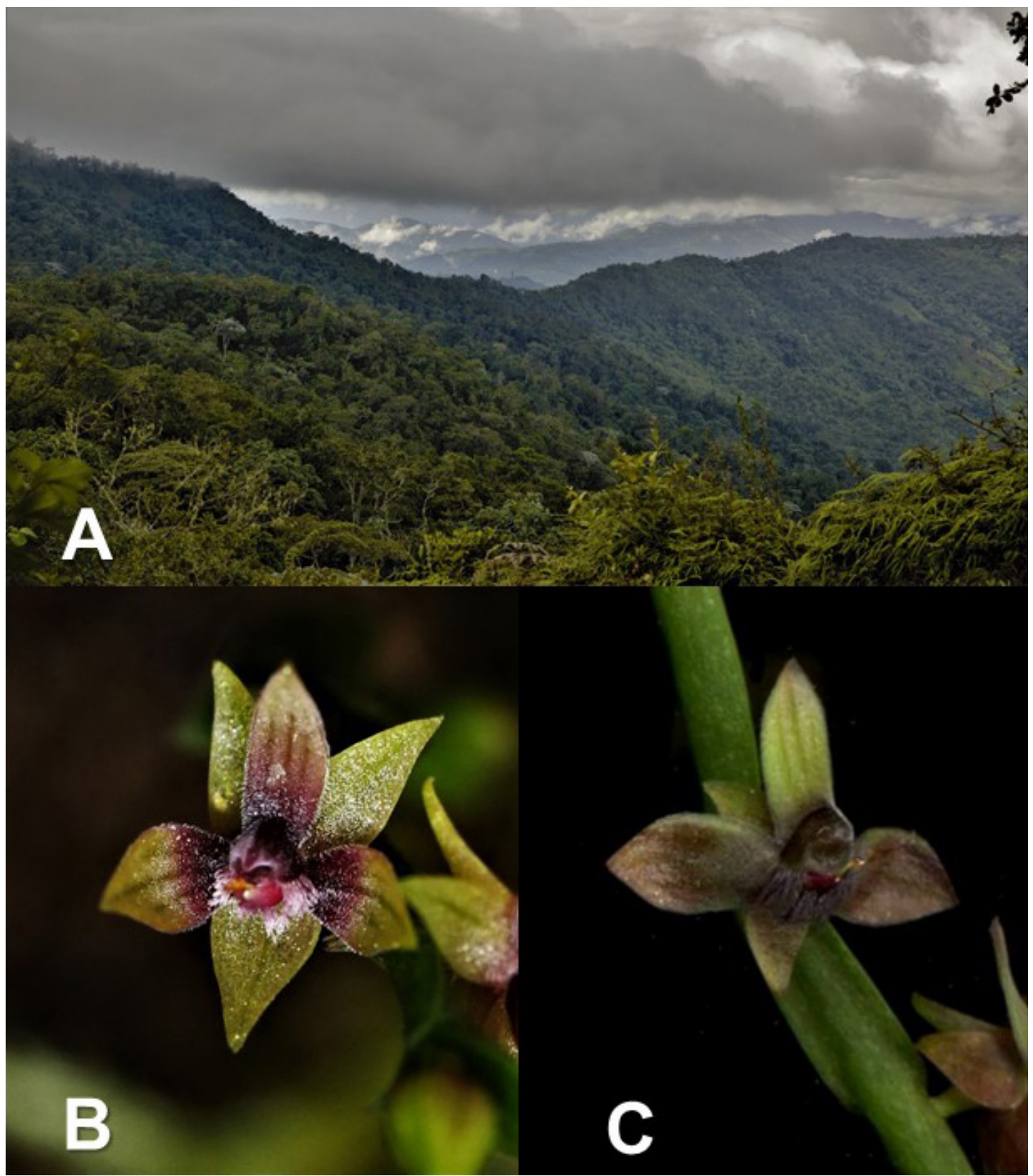

Figure 3. A. Dapa mountains, the type locality of Telipogon mayoi, in western Colombia Andes. B. Flower of T. mayoi (Reina-Rodríguez et al. 2982, CUVC). C. Flower of T. lankesteri (Bogarín 2317, Jardín Botánico Lankester). Photographs from G. Reina-Rodríguez (A-B) and D. Bogarín (C).

pality and La Elvira Protected area) are known and there is no information available on the populations. Therefore, it must be classified as a data deficient (DD), following the IUCN Red List criteria (IUCN 2019).
ECOLOGY AND DISTRIBUtion: Telipogon mayoi is endemic to Colombia and it is known from two localities in the Corregimiento of Dapa and La Elvira protected area in the Yumbo Municipality, Valle del Cauca Department. Plants of T. mayoi grow in the montane for- 
ests of western Colombian Andes between 2000-2100 $\mathrm{m}$, which presents steep slopes and well drained soils of volcanic origin from the Cretaceous (CVC 2009). Weather conditions in the area were reported as presenting between 1900-2100 mm annual precipitation and between $15^{\circ} \mathrm{C}$ and $17^{\circ} \mathrm{C}$ annual temperature average (CVC 2009). According to Holdridge (1987), this area can be classified as Montane rain forest, more widely known as subandean forest.

The habitat, where T. mayoi is found, is dominated by Brunellia comocladifolia Bonpl., Alchornea latifolia Sw., Hedyosmum bonplandianum Kunth and Billia rosea (Planch. \& Linden) C.Ulloa \& P.Jørg. Plants of T. mayoi grow on shrubs of Meriania Sw., Tibouchina Aubl. and Psidium L. (Perez-Escobar et al. 2011) We observed it growing on shurbs of Miconia cauda DC. The community of epiphytes in Dapa is dominated by Cyrtochilum Kunth, Oncidium Sw., Epidendrum L., Pleurothallis R.Br., Masdevallia Ruiz \& Pav. and Lepanthes Sw. (Baker 2019).

Additional material: Municipio de Yumbo, Corregimiento de Dapa, via Bitaco, cerca de la Hacienda "Los Españoles", 2039 m, O. Perez \& M. Kolanowska 872 (VALLE!).

Discussion. Plants of T. mayoi were first recorded some years ago as T. lankesteri by Pérez-Escobar et al. (2011), which came from a forest just $4.1 \mathrm{~km}$ far from the type locality (Fig. 4). This misidentification is understandable since $T$. mayoi and T. lankesteri belong to the miniature Telipogon group and some individuals, recorded by Pérez-Escobar et al. (2011), did also lose the leaves during blooming, as T. lankesteri does. However, there are clear morphological differences between T. mayoi and T. lankesteri (see Zambrano Romero et al. 2018; Table 1), and not all the plants of $T$. mayoi lose leaves during blooming. Thus, T. mayoi possesses leaves with crenulated margins (instead of entire margins in T. lankesteri), an ovate oblong lip (instead of an oblong lanceolate lip in T. lankesteri), with ciliate margins in the lip (instead of entire margins in $T$. lankesteri), furcate setae on the column (instead of simple setae on the column in T. lankesteri). To the best of our knowledge, there is no real material of $T$. lankesteri recorded from Colombia, so it seems it does not occur there. Telipogon

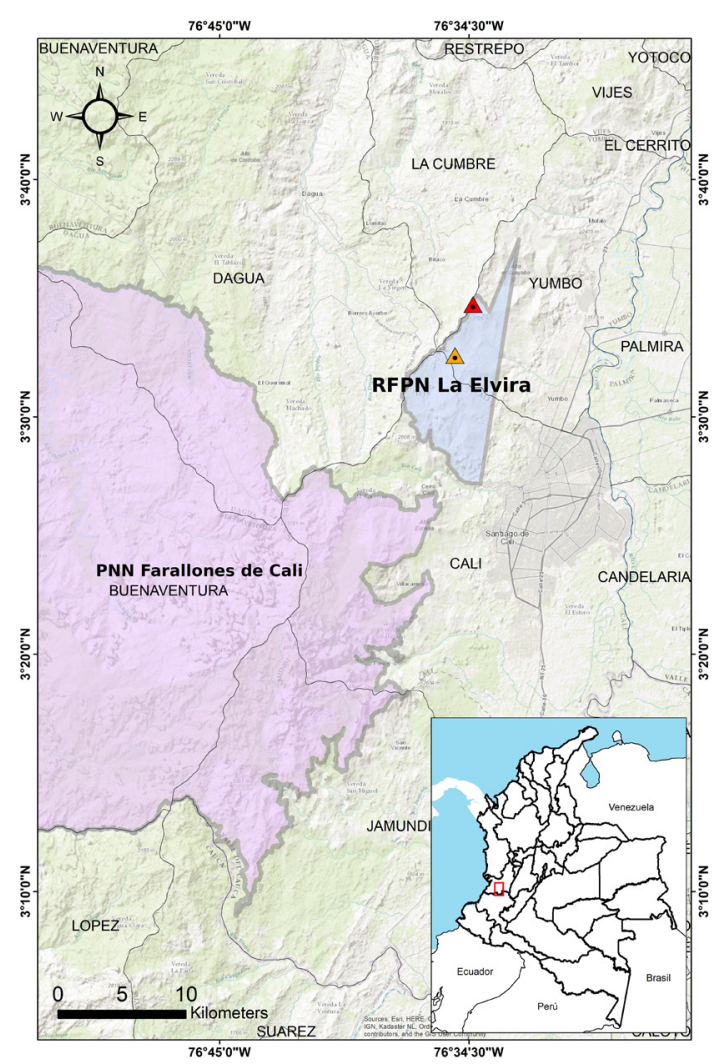

FIgURE 4. Distribution map of Telipogon mayoi. Red triangle indicates the type locality and orange triangle represents the record of Pérez-Escobar et al. (2011). PNN: National Natural Park Farallones de Cali (196350 ha); RFPN: National Protective Forest Reserve La Elvira (7064 ha). Base map ESRI. Map elaborated by Kevin Reyes.

mayoi is similar to T. williamsii in the habit; however, $T$. mayoi is easily differentiated by the simple lip (instead of the bilobed lip in T. williamsii) with absence of a callus (instead of a distinctive callus in T. williamsii) and the densely furcate setae (instead of few, simple setae in T. williamsii; see Table 1). Plants of Telipogon mayoi slightly resembles those of $T$. sonia-juaniorum Zambrano, Bogarín \& Solano from Ecuador, as both species have small plants and their flowers present 3 tufts of setae on the column. However, T. mayoi can be recognized by the ovate oblong lip (instead of the elliptic lip in T. sonia-juaniorum), the half of the flower diameter in T. sonia-juaniorum than $T$. mayoi and the furcate setae (instead of mainly simple setae in T. sonia-juaniorum; Table 1). 
TABLE 1. Differences in distributional range, abiotic and biotic characters between Telipogon mayoi, T. lankesteri, T. sonia-juaniorum and Telipogon williamsii.

\begin{tabular}{|c|c|c|c|c|}
\hline & Telipogon mayoi & Telipogon lankesteri & Telipogon williamsii & Telipogon sonia-juaniorum \\
\hline \multicolumn{5}{|l|}{$\begin{array}{l}\text { Distributional and } \\
\text { abiotic conditions }\end{array}$} \\
\hline Distributional range & $\begin{array}{l}\text { W. Colombian } \\
\text { Andes, middle lands }\end{array}$ & $\begin{array}{l}\text { Caribbean Costa Rican } \\
\text { lowlands }\end{array}$ & $\begin{array}{l}\text { Andes Colombia, } \\
\text { Ecuador and Ve- } \\
\text { nezuela, middle lands }\end{array}$ & $\begin{array}{l}\text { SW. Ecuadorian Andes, } \\
\text { middle lands }\end{array}$ \\
\hline $\begin{array}{l}\text { Life zone (sensu Hold- } \\
\text { ridge 1987) }\end{array}$ & Montane rain forest & Tropical moist forest & Montane rain forest & Premontane moist forest \\
\hline Habitat & $\begin{array}{l}\text { Secondary cloud } \\
\text { forest }\end{array}$ & Secondary moist forest & $\begin{array}{l}\text { Secondary cloud } \\
\text { forest }\end{array}$ & $\begin{array}{l}\text { Semi-deciduous montane } \\
\text { forests }\end{array}$ \\
\hline Elevation range $(\mathrm{m})$ & $2000-2100$ & 800 & $1800-2550$ & $1100-1300$ \\
\hline $\begin{array}{l}\text { Mean annual rainfall } \\
(\mathrm{mm})\end{array}$ & 1800 & 2800 & $1800-2272$ & 1477 \\
\hline $\begin{array}{l}\text { Annual mean tempera- } \\
\text { ture }\left({ }^{\circ} \mathrm{C}\right)\end{array}$ & 14.2 & 22.8 & 17.4 & 22.4 \\
\hline \multicolumn{5}{|l|}{$\begin{array}{l}\text { Morphological and/ } \\
\text { phenological condi- } \\
\text { tions }\end{array}$} \\
\hline Habit & Epiphyte & Epiphyte & Epiphyte & Epiphyte \\
\hline Flowering period & May-June & September & January, May, July & June and September \\
\hline Leaf blade size (mm) & $4-8 \times 2-2.5$ & $7-15 \times 1-2$ & $40 \times 12$ & $5-7 \times 2.5-3.0$ \\
\hline Leaf blade margin & serrulate & entire & entire & crenulate \\
\hline $\begin{array}{l}\text { Inflorescence length } \\
(\mathrm{cm})\end{array}$ & ca. 4.0 & ca. $20.0-23.0$ & ca. $4.0-8.0$ & ca. 5.5 \\
\hline Sepal size(mm) & $4.0-4.1 \times 1.8-2.0$ & $2.8-3.0 \times 0.8-1.0$ & $5.0 \times 2.0$ & $2.2 \times 1.5$ \\
\hline Flower diameter (mm) & 8.0 & 6.0 & 12.0 & 4.5 \\
\hline Column setae & branched & unbranched & unbranched & simple to rarely furcate \\
\hline
\end{tabular}

ACKNOWLEDGements. The authors are grateful to the Rubiano-Hurtado Family in Dapa, Valle del Cauca. G.A.R. and F.L-M. thank to Kevin Reyes, Diana Carolina Puerto Poveda and her Company Motolombia and Greg Ward from St. Luis, Missouri for supporting the field trip. The authors acknowledge to the Parques Nacionales de Colombia for the license $\mathrm{N}^{\mathrm{o}}$ 074-2018. Thanks to Diego Bogarín for provide the image of T. lankesteri and Janice Valencia for making possible the preparation of this article. C.M. thanks Benjamín Collantes for advice on botanical terminology. Two anonymous reviewers provided helpful comments that improved greatly the manuscript.

\section{Literature Cited}

Baker, K. J. (2019). An investigation into the effects of altitude, habitat type and climate change on orchid communities in the Cauca valley region, Colombia (Master dissertation). Nottingham Trent University, Nottingham, United Kingdom.

Betancur, J., Sarmiento, L. H., Toro-González, L. \& Valen- cia, J. (2015). Plan para el estudio y la conservación de las orquideas en Colombia. Bogotá, Colombia: Ministerio de Ambiente y Desarrollo Sostenible, Universidad Nacional de Colombia.

Collantes, B. \& Martel C. (2015). Telipogon koechlinorum (Orchidaceae), a new species from Machu Picchu, Peru. Brittonia, 67, 113-117.

CVC (Corporación Autónoma Regional del Valle del Cauca). (2009). Aunar esfuerzos técnicos y económicos para realizar el análisis preliminar de la representatividad ecosistémica, a través de la recopilación, clasificación y ajuste de información primaria y secundaria con rectificaciones de campo del mapa de ecosistemas de Colombia, para la jurisdicción del Valle del Cauca. Santiago de Cali, Colombia: Convenio CVC-FUNAGUA No 256/2009, Informe final. 243 pp.

Dodson, C. H. \& Escobar, R. (1987). The Telipogons of Costa Rica (I). Orquideología, 17, 1-69.

Dodson, C. H. (2004). Native Ecuadorian Orchids. 5: Rodriguezia-Zygosepalum. Sarasota, USA: Dodson Trust. 
Govaerts, R., Bernet, P., Kratochvil, K., Gerlach, G., Carr, G., Alrich, P., Pridgeon, A. M., Pfahl, J., Campacci, M. A., Holland Baptista, D., Tigges, H., Shaw, J., Cribb, P., George, A., Kreuz, K. \& Wood, J. (2019). World Checklist of Orchidaceae. Facilitated by the Royal Botanic Gardens, Kew. Retrieved from: http://apps.kew. org/wcsp/ [Accessed on September 10, 2019].

Holdridge, L. (1987). Ecología basada en zonas de vida. San José. Costa Rica: IICA., 216 pp.

IUCN. (2019). Guidelines for using the IUCN Red List categories and criteria. Version 13. Standards and Petitions Subcommittee in February 2017. Accessed from http:// www.iucnredlist.org/documents/RedListGuidelines.pdf

Kolanowska, M., Trejo, R. \& Lipińska, M. (2017). A new species of Stellilabium (Orchidaceae) segregated from S. morganiae. Polish Botanical Journal, 62, 21-26.

Martel, C. (2016a). New records for two Peruvian endemic Telipogon (Orchidaceae) including an unexpected record of Telipogon ariasii. Revista Peruana de Biología, 23, 43-36.

Martel, C. (2016b). Nomenclatural changes in species of Telipogon (Orchidaceae) from Ecuador and Bolivia. Orquideología, 33, 34-37.

Martel, C., Collantes, B. \& Egoavil, L. (2017). Telipogon huancavelicanus sp. nov. (Orchidaceae) from Peru, and an updated description of $T$. deuterocuscoensis. Nordic Journal of Botany, 35, 539-545.

Martel, C. \& Nauray, W. (2013). Notes and an emended description of Telipogon peruvianus (Orchidaceae: Onci- diinae). Candollea, 68, 245-250.

Pérez-Escobar, O. A., Parra Sánchez, E., Kolanowska, M. \& Ortiz, V. P. (2011). Primer reporte de Telipogon lankesteri Ames (Orchidaceae) para Colombia. Orquideología, 28, 36-40.

Pérez-Escobar, O. A., Rodríguez, L. \& Martel, C. (2017). A new species of Telipogon (Oncidiinae; Orchidaceae) from the Paramos of Colombia. Phytotaxa, 305, 262268.

Reina-Rodríguez, G. A. (2016). Aportaciones al conocimiento de las orquídeas del Bosque Seco Tropical y escenarios de cambio climático en Colombia. Doctoral dissertation. Universidad de Barcelona, Barcelona, España. 278 pp.

Reina-Rodríguez, G. A. (2019). Orquídeas del predio el Danubio. Una ventana a la flora escondida de los Farallones de Cali. Andes occidentales de Colombia. Guía ilustrada. Santiago de Cali, Colombia: Departamento Administrativo de Gestión del Medio Ambiente (DAGMA) y Corporación Autónoma Regional del Valle del Cauca (CVC). Santiago de Cali, 44 pp.

Williams, N. H., Whitten, W. M. \& Dressler, R. L. (2005). Molecular systematics of Telipogon (Orchidaceae: Oncidiinae) and its allies: nuclear and plastid DNA sequence data. Lankesteriana, 5, 163-184.

Zambrano Romero, B. J., Bogarín, D. \& Solano, R. (2018). Telipogon sonia-juaniorum (Orchidaceae: Oncidiinae) a new species from Southwestern Ecuador. Phytotaxa, 340, 167-174. 